\title{
The Pain of Teaching: Considerations Regarding Educational Endeavors
}

\author{
Raisa Pinheiro Arruda, Ana Maria Fontenelle Catrib, \\ Christina Cesar Praça Brasil, Maxmiria Holanda Batista, Patricia Passos Sampaio \\ Universidade de Fortaleza, Fortaleza, Brazil
}

\begin{abstract}
This article discusses the daily work of teachers in public elementary schools in the city of Fortaleza, Ceará, Brazil. Action research was performed as a practical activity in the discipline of management processes and worker health. The research was conducted in a municipal school and aims to understand how teachers handle their daily lives from the changes in the working world, taking into account the ways in which such transformations bolster health or illness among these professionals. Discussion groups were held, from which the following themes emerged: the role of the teacher, feelings arising from teaching activities, and favorable aspects and difficulties in the daily lives of teachers. The teachers interviewed showed a strong sense of frustration at the idealization of the teaching practice in contrast with the current education scenario and the constant social devaluation of the profession. The teachers often experience feelings of frustration, helplessness, anxiety, discouragement, and fatigue, but also, occasionally, joy, satisfaction, and hope. There are urgent measures that can change this situation with a focus on health promotion and the improvement of teachers' quality of life.
\end{abstract}

Keywords: teaching, health promotion, action research

\section{Introduction}

The world of work has undergone changes throughout history. In antiquity, work was associated with manual, menial activities, and therefore, intended for slaves who labored under duress. With the advent of capitalism and work in the form of paid employment, the home environment and the workplace have become separate entities. Ever-increasing industrialization and urbanization - transition from an agricultural economy to an industry-based economy - generated the Taylor-Ford model of organization, in which work is organized as the need for standardization of procedures for control and strict discipline (Antunes, 2002; Dejours, 2004; Zanelli, 2004).

From the mid-20th century, a number of changes have impacted the world of work, among them are increased competition, automation of production, revolution of the media, new forms of management (total

Raisa Pinheiro Arruda, Bachelor of Psychology, Universidade de Fortaleza.

Ana Maria Fontenelle Catrib, Ed.D., Doctoral Degree in Colletive Health, professor, Graduate Program in Collective Health, Universidade de Fortaleza.

Christina César Praça Brasil, Doctoral Degree in Colletive Health, professor, Graduate Program in Collective Health, Universidade de Fortaleza.

Maxmiria Holanda Batista, Master Degree in Colletive Health, professor, Graduate Program in Psychology, Universidade de Fortaleza.

Patricia Passos Sampaio, Master Degree in Colletive Health, professor, Graduate Program in Psychology, Universidade de Fortaleza. 
quality management, participative management, and Toyotism), the Internet, and flexibility of production. Contemporary organizations are structured to eliminate, where possible, repetitive activities, requiring another worker profile that emphasizes versatility and constant qualification while focusing on new technologies, market relations, and competition.

This form of work organization directly impacts the activities of Western teachers. Schools have taken on the task of preparing the market for skilled labor, and therefore need to adapt constantly to the demands of this new economic model; schools now act within the paradigm of efficiency and productivity, as well as fulfilling a social role that was traditionally a family function. Thus, educating children has also become the teacher's role (Weschenfelder \& Trindade, 2011).

The new economic configuration requires livelier, more intellectualized workers. Globalization —which is based on neoliberal logic and reaffirms the logic of capital accumulation fastest_-brings a discourse that seeks the withdrawal of the state from the economic process and opens the possibility of a market-run society. (Corrêa \& Pimenta, 2005). This debate is absorbed by the school as it continues to perform its task of training individuals who seek productivity in a classroom structure aimed at rationalization and the specificity of knowledge that results in skilled and multi-specialized labor.

Thus, education takes on the molds of the market. That is, the products - students - must be measurable and fully immersed in the new production standards. This measurement relies on indices of assessments and rankings of students who pass standardized tests and contests. "Until the Second Industrial Revolution lived affection and work in healthy confusion" (Codo \& Gazzotti, 1999, p. 48), but after the Taylor-Ford organization, there was a modification and rigid division of spaces that separated affection, love, and care from the act of teaching. Consequently, the school has transformed into a place where rationality and bureaucracy must prevail.

In this context, the requirements of teaching intensify. A teacher, previously an educator who would enable his/her students to know the world and act as protagonists of society, now proceeds to meet the demands of the capitalist system more forcefully. The new role is to train skilled individuals for the labor market: skilled professionals committed to quality, efficiency, and effectiveness of services. A teacher is an "agent of human formation able to prepare youth for the global world, an uncertain world where people are increasingly subjected to market instability that constantly adjusts to increase profits" (Claro, 2009, p. 15). Thus, the process of student learning is sacrificed for evaluations of student performance based on results.

Presently, teachers simultaneously face the social devaluation of their profession and the increasing demands of their role, namely, systematic qualification, management of information technologies, classroom profile management, among others. The demands intensify, however; conditions are not appropriate for the exercise of their professional activities, since teachers often likewise confront precarious working conditions as well (Freitas, 2013).

Given this context, what feelings do the teachers have ascribe to teaching activities? How do they face the current requirements of the labor market in their classroom routine? And how does this context affect the health and quality of life of the teachers?

In order to think about such issues, the objective of this study is to comprehend how teachers deal with their daily lives within this evolving world of work while taking into account the ways in which such transformations may affect their subjectivity and produce wellness/illness changes. 


\section{Methodology}

The focus of this research lies squarely upon a subjective, and therefore transformative, aspect of reality (Clot, 2007).

This is a qualitative study that used the action research method. Action research earned space among the social sciences by defending the idea that "Scientists should come out of their isolation, assuming the consequences of their research findings, and put them into practice to influence the course of events" (Engel, 2000, p. 182). Thus, action research enhances practice through systematic oscillation between acting in the field of practice and researching that field. "Action research enables a process wherein a change for the betterment of practice is planned, implemented, described, and evaluated, learning more throughout the process both about the practice and the research itself" (Tripp, 2005, p. 446).

Action research is situational and disinterested in generalizable results. Instead, it seeks practical relevance in order to provide immediate feedback. Once, a researcher intervenes in a situation, he/she can check whether the procedure is effective or not and thus adapt his/her actions (Engel, 2000).

Another feature of action research consists in encouraging the participation of the people involved that can reflect and modify their working conditions and life in the community. For this, explanations from the participants themselves are sought, and so initial members of the community become researchers as well. Thus, they cultivate their own knowledge as they are implicated in this production (Neto, 2012).

This research involves "engaged participants, as opposed to traditional research" (Engel, 2000, p. 182) which seeks to intervene in the course of the investigation. To this end, this work allowed for the creation of devices which permitted the individuals to turn their reality into a new life experience. So, here the challenge was to intervene in order to transform.

In order to collect information, this study used organized focus groups in an effort to obtain in-depth participant opinions regarding determined themes. With such groups, the principal objective is to focus on participant perceptions (Gomes \& Barbosa, 1999). For this, focus groups require a small number of people who share experiences with the subject under scrutiny as well as a profound knowledge of the factors that affect the most pertinent data. Roughly 10 participants should participate in sessions of one to two hours, discussing few topics in depth, in order to yield the greatest number of relevant ideas (Gomes \& Barbosa, 1999; Trad, 2009).

The interaction of the participants of the focus group facilitates the formation of new and original ideas, generating possibilities contextualized by the group itself, as well as nurturing the interpretation of beliefs, values, concepts, conflicts, clashes, and viewpoints (Ressel, Beck, Gualda, Hoffmann, Silva, \& Sehnem, 2008).

In this study, encounters capitalized on the artistic production of the participants as thematic triggers for the discussion of topics linked to school and the practice of teaching. During the process, as necessities arose, interventions were planned for each topic presented as a problem.

During the investigation, complaints about communication, relationships, and professional development resonated among the participants. To the extent that such complaints were discussed, actions were also planned that would be developed to minimize the effects of such problems in the health and quality of life of teachers. Thus, once the interventions occurred, we received immediate feedback, and those interventions that rendered positive returns remained as continuous actions. Those that did not cause positive impacts, or that were feckless, were redesigned or removed. 
Seventeen meetings were held with groups of teachers, each having 6-10 participants per meeting and lasting for about two hours. The meetings occurred in a library, as it was the only reserved environment in the school.

The group consisted mostly of females; only one participant was male. The teachers were between 25 and 35 years old and held postgraduate diplomas. All of the teachers instructed their classes in elementary education Level I and II.

The invitation to the teachers was made upon presentation of the intervention plan in a meeting with all the teachers at the school. Participation was free. There were no exclusion criteria for teachers, since the aim of the work was to understand the relationships between the teachers and the school.

Over the course of the groups, the following topics were discussed: (a) the role of teachers; (b) the feelings arising from teaching activities; and (c) favorable aspects and difficulties faced by the teachers in their daily lives.

Information obtained through the focus groups and observations was analyzed, taking into account general aspects of the speech of teachers, and the meaning they attach to their teaching activities.

For data analysis, we used the Analysis of Discourse, because according to Guirado (1997), "It is the nature of the material we work with that conditions their production and their understanding, as a fact of language that defines the orientation paid to the analysis of discourse we do" (p. 25). Maingueneau (2006) argued that:

Speech is an organization of restrictions that regulate a particular activity. The enunciation is not an illusory scene where such contents would be said elsewhere, but a constitutive device for the construction of meaning and the subjects who therein are recognized. (p. 50)

Therefore, in this research, the speech of a "psychic, affective, and institutional" subject gave us access to its subjectivity. This meets the objectives of the research, since investigating the perceptions that the teachers have regarding their teaching role is much more than seeking a direct, concrete sense, as if its meaning were extracted from the dictionary; instead, we sought meanings full of uniqueness and fraught with subjectivity.

\section{Results and Discussion}

Regarding the favorable aspects of their work, speech teachers corroborate what is written in literature (Mazon, Carlotto, \& Câmara, 2008; Poncinho \& Capelo, 2009; Santos, Antunes, \& Bernardi, 2008; Santos, 2006), mentioning that they are constantly challenged to learn the positive relationships with peers and students, as well as the possibility of transmitting knowledge, and especially the satisfactory performance of the students. Such are considered the most relevant and positive aspects of their profession.

It is really positive when we spell out the problems and the students can find their solution. (Interviewee C)

When we are able to get a place where we can give our class and count on the students' participation and engagement, it's really gratifying. (Interviewee A)

(...) It is marvelous when you meet a former student who is doing well that says he learned with you. (Interviewee D)

With regard to the difficulties encountered, the following factors were identified: lack of limits for the students; the low level of learning; indiscipline; violence; aggression; and lack of interest, commitment, and attention. Regarding the school, there are not enough resources to teach classes, no time for planning, disorganization, and unnecessary politics that permeate management. Besides these difficulties, teachers also 
lack the involvement of families in the students' learning process.

Such aspects corroborate Neves and Silva (2006), who reported in their research on elementary school teachers in northeastern Brazil, that a major complaint of teachers is the lack of social recognition and the consequent devaluation of the profession, as well as feeling guilty for the failure of public schools.

Freitas (2013) affirmed that the current context of teaching can be described as follows: urgency in transmitting content is prized over the real needs of students; lack of training of teachers; difficulty for students to stay attentive to the content taught in class; unfavorable conditions; societal demands for more and higher quality schooling; crushing workload; and social devaluation of the profession. This shows similarity with the results.

Being a professor is not like it used to be (...), there is not any respect for professors. (Interviewee B)

Our career is not valued (...), you do not get a good salary and they always ask you to give more (...), you have to work miracles and nothing changes in your paycheck. (Interviewee F)

According to Mendes (2007):

In the words of the teachers, it is possible to notice an emptying of reflections on the impact of socio-economic context on the professions, especially teaching, with regard to material possessions and a lack of recognition. It is noteworthy that this context, which does not recognize the efforts of the teacher, negatively impacts the mental health of these workers. (p. 271)

For Paschoalino (2008), with the advance of capitalism, the teaching profession has passed, over time, through tense situations in search of an identity. Additionally, the profession has always faced questions and judgment for its actions based on the perspective of teaching as a singular activity and not as a complex fabric of relationships doing many jobs.

The extensive workload was another aspect pointed out by the teachers as a difficulty in their daily lives. In an attempt to achieve a wage closer to ideal, teachers have intensified their workloads of planning and elaborating their work. Their time is busied most frequently with bureaucratic requirements-filling in their agendas, publishing grades, lesson planning, preparation of periodic evaluations of students, among other assignments.

It is an extremely tiring job. At the end of the school year, we bear the students and the students bear us (...). (Interviewee B)

A teacher that works three jobs in order to maintain a reasonable salary indirectly proposes to his students that what is important is "having"; to have and to maintain a good car and other material goods that are unattainable for the students. This professor does not plan his classes, does not care for his own health; he cannot have loving attention for his class. (Interviewee E)

When the school becomes a work organization for marketing purposes, within a model focused on the effectiveness, efficiency, and competitiveness, the teachers find themselves in an environment that, rather than stimulating creativity, puts them face to face with the bureaucratization of teaching. This occurs beginning when the learning process stops being primordial in the teacher's function, and space gives way to measure, by way of ratings, the students' abilities to absorb content; such ratings likewise are also given to judge the ability of the teacher to carry on his/her work.

Still regarding the extensive workload, time to perform tasks was a factor present in the discourse of our respondents, since they need to devote time to a higher workload allocated to the school for other 
complementary activities, which includes weekends, holidays, and time with family. The need to make available a grand portion of their time for teaching has become evident, which requires a lot of sacrifices. The interviewees reported also not having time to seek improvement and further study themselves to meet the demands of evolving profession.

Continuing education is necessary, but we do not have time to participate; the workload is too high for even the things we need in order to do the things we need to. (Interviewee B)

We work too much and we do not have time to take care of our own children at home. (Interviewee G)

The violence presenting in some neighborhoods of Fortaleza is seen as another impediment to satisfactory performance according to the discourse of the teachers. Increased violence in schools decreases the willingness of teachers to establish any connection with the students, in addition to planting fear, sometimes paralyzing fear, thereby preventing the free exercise of teacher creativity and autonomy in the classroom.

Our job is very insecure. You do not feel protected or watched over. (Interviewee E)

It is an overarching insecurity (...). Students do not accept limits, they threaten violence, and there is no punishment (...). The school does nothing. (Interviewee F)

With respect to the sense of teaching activities, the teachers attributed a sense of utmost importance. One of them said, and others agreed, that a teacher "should be a seller of dreams", that is, it is for the teacher to provide opportunities to discover talent and potential among his/her students.

My work is very important, as I think it makes a difference in the lives of children. I plan what I do and this is fundamental (...). I propose happiness and creativity. I do not always succeed (...), but I like what I do. (Interviewee A)

The professor should be a seller of dreams (...). (Interviewee D)

However, according to the teachers, a number of difficulties experienced in everyday life (lack of teaching resources and lack of student interest) have undermined and sometimes prevented the transformation and improvement of society—objectives pursued during teaching activities.

It is such a shame. (...) It seems that this work is for naught. Student disinterest is very large. This messes with the teacher's self-esteem. He wants to do something but he does not know how. (Interviewee C)

The relation of the teacher to the transmission of knowledge ends up being a sterile pedagogy. We pretend to teach and the students pretend to learn (...). (Interviewee B)

(...) I have the feeling of just filling the workday, but not producing any real result. We have so many ideas but the classes are bogged down by the noise and indiscipline of the students. (Interviewee D)

Nevertheless, when asked about the main feelings arising from their work, the teachers mentioned joy, satisfaction, and hope when they see the fruits of their labor.

Still, market requirements affect teachers daily, relating to the technical education to respond adequately to the market needs. In the classroom, a teacher says that it is necessary to focus more on the content than on the relationship with the students. Thus, a job that was previously permeated by affectivity becomes objectified by the goals and outcomes that it must achieve.

We know that one factor that differentiates teaching from other jobs is the emotional bond that is established between teachers and students. Besides involving affection, teaching is not fragmented, which means that teachers have control over the scope of the objectives of their work process. Thus, teachers become responsible for the results, recognizing them as their own (Olivier-Heckler \& Soratto, 1999). 
I immensely love what I do. I love the contact with the younger public. I feel hope when students ask and clarify their questions, when they participate in class, or even more simply, when they wait for me by the door with a smile. (Interviewee D)

When I realize that learning has occurred, I feel such happiness, such satisfaction. (Interviewee G)

The peculiarity of the teacher's work lies precisely in the fact that affectivity is mandatory in the profession (Codo \& Gazzotti, 1999). The objective of a teacher's work is student learning, and for this to occur, there must be affection on the part of the teacher towards his/her students, so that they might feel motivated, interested, and conquered by the knowledge that the teacher wants to convey (Codo \& Gazzotti, 1999).

Nonetheless, the fact that responsibility for the production of results remains under the control of the teacher makes the pressure and anxiety grow due to expectations, because any scholastic failure or performance problems fall upon the teacher, causing feelings of guilt.

When learning is not possible, the interviewees relate feelings of anxiety, discouragement, helplessness, insecurity, and frustration, as some of them said:

The classroom, many times, demotivates. Sometimes, it seems like we are in a battleground. It is too much. It causes disanimation and sadness. (Interviewee $\mathrm{H}$ )

I feel frustrated sometimes when I do not see any return for my work, when I just feel the disinterest, the low grades, and the indiscipline. (Interviewee E)

I feel, sometimes, frustrated by the low return, the disinterest in class, and the absences. (Interviewee C)

I feel frustrated when I cannot give a good class because of discipline. The worst is when you spend a whole month on a subject and when the time comes to evaluate you see a grade of 0 or 2 out of $10(\ldots)$. Now, it is wonderful to see an old student who is doing well say he learned with you. (Interviewee D)

I feel frustrated knowing that I am not making a difference (...). I cannot even do the obvious: teach a class. (Interviewee E)

This phenomenon of extreme responsibility of the teacher for his/her work and concern for the students can be explained, according to Codo (1999), because the teacher is a type of worker who develops a labor wherein individualized attention to the other acts as the difference between performing or not performing the duty. It is a job that takes into account the affective bonds with the students, with the product, and with the tasks; without such affection, the job is simply not feasible.

Confirming this idea, Tardif and Lessard (2005) argued that educational work is full of meaning and to achieve it, each teacher has to establish emotional bonds with the "object" of his/her work-the students. Thus, the job of an educator is not marked by objectivity, but by meaning or symbolic meaning. In it, each teacher must enroll relationship with the other in the very core of knowledge (Dejours, 1992).

These aspects were perceived when the teachers said that because of the impossibility of establishing an emotional bond and arousing the interest of students about the content the informants teach, they feel frustrated and discouraged with their work. Moreover, the professors feel a lack of support from school management which would enable them to enhance their lessons and build a work environment that provides for creative and dynamic work.

There are moments when I feel impotent because of the situations in school. We cannot talk about a necessity for a better day-to-day quality at school. I see that people are working automatically, frenetically, without reflection (...) and the structure lacks chairs, coffee cups, snacks (...) it lacks a path. We do not have an arrow showing the way. The coordination only wants results. They do not give support. (Interviewee D)

In the words analyzed were present grievances involving wages, social devaluation, and the distance from 
the family, and these can be seen as demands for interventions aimed at healthy teachers.

Batista (2011) highlighted that:

The responsibility of the role that the teacher expressed evokes a sense of outrage and grief in the face of the devaluation of teaching by society, given that teaching is perceived as very stressful, separates the family, and demands a lot of physical and emotional effort. (p. 78)

These aspects highlight the need to broaden the discussion on public policies in education and health, since dissatisfaction with wages and social impairment are factors that directly influence the quality of life and overall wellbeing of teachers and directly undercut the results of their work.

Thus, we are reminded of the ideas of Bicudo-Pereira, Penteado, Bydlowski, Elmor, and Grazzelli (2003), that defined of the need for urgent health promotion interventions for teachers who, being ill and unhappy, will not be able to implement the ideas and proposals of health promotion in their lives or in the schools in which they work.

\section{Final Considerations}

By perceiving the pains of teaching, the teachers understand that the accomplishment of the objectives of education lies beyond the sheer willingness of them to teach, and also depends on the conditions of work and how to establish the teacher-student relationship.

Besides the emotional relationship with the students, the teachers relate emotionally with the work itself, and since such investment brings no return or recognition, the subject may experience intense suffering.

In this way, a professor's work remains fixed between the subjectivity of its function and the objectivity demanded by the world of work. Within such ambiguity, teachers may feel sentiments of frustration, anxiety, anguish, and stress; therefore, special attention must be paid to the promotion of health and quality of life for this professional category.

Thus, the school space constitutes a fertile ground for health-related demands by professionals who concern themselves with their physical and psychological health. Researchers and research participants notice the necessity of systematic interventions in efforts to prevent health disturbances. Such interventions can anticipate foreseeable crises in a precarious and intense work context, such as the teaching environment.

We consider that beyond the work of prevention, such interventions must take on a character of health promotion and quality of life betterment in the teaching space so that teaching transforms from its current status as painstaking and sickening work into a fulfilling and wellbeing-centric profession. The necessity for urgent public policies is clear: professors require esteem, just salaries, and attractive work environments in order to find meaning in their work of teaching children in the first years of school.

\section{References}

Antunes, R. (2002). Os sentidos do trabalho: Ensaio sobre a afirmação e a negação do trabalho (The meanings of work: Essay on the affirmation and negation of work). São Paulo: Boitempo.

Batista, E. (2011). Fordismo, Taylorismo e Toyotismo: Apontamentos sobre suas rupturas e continuidades (Fordism, Taylorism and Toyotism: Notes on their ruptures and continuities). Retrieved from http://www.uel.br/grupo-pesquisa/gepal/terceiro simposio/erika_batista.pdf

Batista, M. H. B. (2010). A afetividade e a promoção da saúde na escola: A construção de significados pelo professor (The affectivity and the health promotion at school: The construction of meanings by the teacher) (Master's thesis, Universidade de Fortaleza, Fortaleza). 
Bicudo-Pereira, I. M. T., Penteado, R. Z., Bydlowski, C. R., Elmor, M. R. D., Grazzelli, M. E. (2003). Escolas promotoras de saúde: Onde está o professor? (Health promoting schools: Where is the teacher?). Saúde em Revista, 5(11), 29-34. Retrieved from http://www.unimep.br/phpg/editora/revistaspdf/saude11art04.pdf

Claro, G. (2009). Trabalho docente e saúde mental: Um estudo de estresse no sistema de ensino municipal de Curitiba (Teaching work and mental health: A study on stress in the municipal school system of Curitiba) (Master's thesis, Universidade Tuiuti do Paraná, Curitiba).

Clot, Y. (2007). A função psicológica do trabalho (The psychological function of work) (2nd ed.). (A. Sobral, Trans.). Petrópolis, R.J.: Vozes.

Codo, W. (1999). Educação: Carinho e trabalho (Education: Endearment and work). Petrópolis, R.J.: Vozes.

Codo, W., \& Gazzotti. (1999). Trabalho e afetividade (Work and affectivity). In W. Codo (Org.), Burnout, a síndrome da desistência do educador, que pode levar à falência da educação (Burnout, the teacher's abandonment syndrome that may lead to education collapse) (pp. 48-59). Petrópolis, R.J.: Vozes.

Corrêa, M. L., \& Pimenta, S. M. (2005). Teorias da administração e seus desdobramentos no âmbito escolar (Theories of administration and their development in schools). In M. A. M. Oliveira (Org.), Gestão educacional: Novos olhares, novas abordagens (Educational management: New looks, new approaches) (pp. 22-39). Petrópolis: Vozes.

Dejours, C. (1992). A loucura do trabalho (The madness of work). São Paulo: Cortez.

Dejours, C. (2004). Subjetividade, trabalho e ação (Subjectivity, work and action). Revista Produção, 14(3), 27-34.

Engel, G. I. (2000). Pesquisa-ação (Action research). Educar, 16, 181-191.

Freitas, L. G. (Org.). (2013). Prazer e sofrimento no trabalho docente: Pesquisas Brasileiras (Pleasure and suffering in teaching work: Brazilian research). Curitba, P.R.: Juruá.

Gomes, M. E., \& Barbosa, E. F. (1999). A técnica de grupos focais para obtenção de dados qualitativos (Focus group technique for collecting qualitative data). Retrieved from http://www.tecnologiadeprojetos.com.br/banco_objetos/\%7B9FEA090E98E9-49D2-A638-6D3922787D19\%7D_Tecnica\%20de\%20Grupos\%20Focais\%20pdf.pdf

Guirado, M. (1997). Psicologia institucional (Institutional psychology). São Paulo: EPU.

Maingueneau, D. (2006). Termos-chave da análise do discurso (Key terms of discourse analysis). Belo Horizonte, M.G.: UFMG.

Mazon, V., Carlotto, M. S., \& Câmara, S. (2008). Síndrome de burnout e estratégias de enfrentamento em professors (Burnout syndrome and coping strategies in teachers). Arquivos Brasileiros de Psicologia, 60(1), 55-66.

Mendes, A. M. (2007). Da psicodinâmica à psicopatologia do trabalho (From psychodynamics to psychopathology of work). In A. M. Mendes (Ed.), Psicodinâmica do trabalho: Teoria, método e pesquisas (Psychodynamics of work: Theory, method and research) (pp. 29-48). São Paulo: Casa do Psicólogo.

Neto, F. M. (2012). Pesquisa-ação: Aspectos práticos da pesquisa ação nos movimentos sociais e em extensão popular (Action research: Practical aspects of action research in social movements and popular extension). Retrieved from http://www.prac. ufpbde.br/copac/extelar/producao_academica/artigos/pa_a_pesquisa_acao.pdf

Neves, M. Y. R., \& Silva, E. S. (2006). A dor e a delícia de ser (estar) professora: Trabalho docente e saúde mental (The pain and delight of being a teacher: Teaching work and mental health). Estudos e Pesquisa em Psicologia, 6(1), 63-75.

Olivier-Heckler, C., \& Soratto, L. (1999). Os trabalhadores e seu trabalho (Workers and their work). In W. Codo (Ed.), Educação: Carinho e trabalho (Education: Endearment and work) (pp. 89-110). Petrópolis, R.J.: Vozes.

Paschoalino, J. (2008). A complexidade do trabalho docente na atualidade (The complexity of the teaching work today). Proceedings of The Fourth National Seminar on Professional and Technological Education, Belo Horizonte, M.G.. Retrieved from http://www.senept.cefetmg.br/galerias/Arquivos_senept/anais/quarta_tema6/QuartaTema6Artigo2. pdf

Poncinho, M., \& Capelo, M. R. (2009). Vulnerabilidade ao stress, estratégias de coping e autoeficácia em professores portugueses (Vulnerability to stress, coping strategies and self-efficacy among Portuguese teachers). Educação e Pesquisa, 35(2), 351-367.

Ressel, L. B., Beck, C. L., Gualda, D. M. R., Hoffmann, I. C., Silva, R. M., \& Sehnem, G. D. (2008). O uso do grupo focal em pesquisa qualitative (The use of focus group in qualitative research). Texto \& Contexto Enfermagem, 17(4), 779-786.

Santos, B. S., Antunes, D. D., \& Bernardi, J. (2008). O docente e sua subjetividade nos processos motivacionais (The teacher and his/her subjectivity in motivational processes). Educação, 31(1), 45-53.

Santos, G. B. (2006). As estratégias de fuga e enfrentamento frente às adversidades do trabalho docente (Flight or fight strategies towards hardships of the teaching work). Estudos e Pesquisa em Psicologia, 6(1), 128-133. 
Tardif, M., \& Lessard, C. (2005). O trabalho docente: Elementos para uma teoria da docência como profissão de interações humanas (The teaching work: Elements for a theory of teaching as a profession of human interactions). Petrópolis, R.J.: Vozes.

Trad, L. A. B. (2009). Grupos focais: Conceitos, procedimentos e reflexões baseadas em experiências com o uso da técnica em pesquisas de saúde (Focus groups: Concepts, procedures and reflections based on experiences with the technique use in health research). Physis: Revista de Saúde Coletiva, 19(3), 777-796. Retrieved from http://www.scielo.br/scielo.php? script=sci_arttext\&pid=S0103-73312009000300013\&lng=en\&tlng=pt. 10.1590/S0103-73312009000300013

Tripp, D. (2005). Pesquisa-ação: Uma introdução metodológica (Action research: A methodological introduction). (L. L. Oliveira, Trans.). Educação e Pesquisa, 31(3), 443-466.

Weschenfelder, F. Z., \& Trindade, G. A. (2011). Trabalho docente e desenvolvimento capitalista: Uma articulação perversa para a saúde do educador (Teaching work and capitalist development: A perverse relationship to teacher's health). Synergismus Syentifica, 6(1). Retrieved from http://revistas.utfpr.edu.br/pb/index.php/ SysScy/article/view Article/1237

Zanelli, J. C. (2004). Psicologia, organizações e trabalho no Brasil (Psychology, organizations and work in Brazil). Porto Alegre, R.S.: Artmed. 